\title{
Legal progress of e-commerce legislation in Central Asia during the COVID-19 period
}

\author{
Ammar YOUNAS ${ }^{1}$, Aminjon KALANDAROV², Mukhammad Ali TURDIALIYEV ${ }^{3}$ \\ Tashkent State University of Law
}

\begin{tabular}{l} 
ARTICLE INFO \\
\hline Article history: \\
Received October 2021 \\
Received in revised form \\
15 October 2021 \\
Accepted 15 November 2021 \\
Available online \\
25 December 2021
\end{tabular}

Keywords:

E-commerce,

Central Asia,

Internet Business,

Legality,

Tech Law.

\begin{abstract}
At the peak of the 4th Industrial Revolution, the legal systems of different countries are trying to adapt the national legal and law enforcement systems of their states to new business areas and technological innovations. One of these areas is Internet business. This type of commerce was practically not regulated in legal and legal terms. The Central Asian countries are systematically trying to update their legal systems, including laws related to e-commerce. The pandemic has accelerated the adoption of laws regulating e-commerce. Since it is impossible to predict when the pandemic will end, there are opinions that we need to learn to live with it. The economic consequences are directly reflected in the banking and financial, manufacturing, services and foreign trade activities of the economies of the Central Asian countries. This article is an overview of the current progress in the field of e-commerce in Central Asia. Since several legal acts were adopted during the period of COVID-19, a generalized overview of the laws on electronic commerce in the era before COVID-19 is analyzed.
\end{abstract}

2181-1415/C) 2021 in Science LLC.

DOI: https://doi.org/10.47689/2181-1415-vol2-iss11/S-pp170-176

This is an open access article under the Attribution 4.0 International (CC BY 4.0) license (https://creativecommons.org/licenses/by/4.0/deed.ru)

\section{Правовой прогресс законодательства об электронной торговле в Центральной Азии в период COVID-19}

\section{АННОТАЦИЯ}

\footnotetext{
${ }^{1}$ Visiting Professor. Tashkent State University of Law. Tashkent, Uzbekistan. Email: doctorammaryounas@gmail.com. ${ }^{2}$ Lecturer, Faculty of Private Law, Department of Business Law, Tashkent State University of Law. Tashkent, Uzbekistan. Email: aminjonqalandarov9@gmail.com.

${ }^{3}$ Lecturer, Faculty of International law and comparative legislation, Department of International Private Law, Tashkent State University of Law. Tashkent, Uzbekistan. Email: m.turdialiyev@tsul.uz.
} 


Ключевые слова:
электронная коммерция,
Центральная Азия,
Интернет-бизнес,
Законность,
Техническое право.

На пике 4-й промышленной революции правовые системы разных стран, пытаются адаптировать национальные юридические и правоприменительные системы своих государств, к новым направлениям бизнеса, и к технологическим инновациям. Одно, из этих направлений - интернет-бизнес. Такой вид коммерции был практически не отрегулирован в юридическом и правовом плане. Страны Центральной Азии, планомерно пытаются обновить свои правовые системы, включая в них законы, связанные с электронной коммерцией. Пандемия ускорила принятие законов регулирующих электронную коммерцию. Поскольку, невозможно, предсказать, когда пандемия закончится, есть мнения, что нам нужно научиться жить с ней. Экономические последствия непосредственно отражаются в банковской и финансовой, производственной, сфере услуг и внешнеторговой деятельности экономик стран Центральной Азии. Эта статья представляет собой, обзор современного прогресса в сфере электронной коммерции Центральной Азии. Поскольку, в период COVID19 было принято несколько правовых актов, анализируется, обобщенный обзор законов об электронной торговле в эпоху до COVID-19.

Central Asia has tremendous e-commerce potential as access to mobile devices and the Internet continues to grow, especially with the rise in popularity of digital payments, increased government support initiatives, and an overall post-economic recovery. At the same time, much of this potential lies in the fact that Central Asia is a developing region with underutilized financial innovation and e-commerce capabilities. Fully expressing ourselves, there is an urgent need for comprehensive national development plans that address issues related to financial inclusion and how to successfully implement practical e-commerce solutions.

\section{KYRGYZSTAN}

The country is developing a strategy for e-commerce development for 20212025 and the Ministry of Economy and Finance is discussing the legal framework and tax regulation necessary for it on different platforms. The sphere of E-commerce is one of the potential boosts of the Kyrgyzstan economy. In 2019, Ministry of Economy with the support of the German Society for International Cooperation presented the Draft Law of the Kyrgyz Republic "On Electronic Commerce" and draft Resolution of the Government of the Kyrgyz Republic "On Approval of the Draft Law of the Kyrgyz Republic" On Electronic Commerce". The bill has been submitted for public discussion. If adopted, the republic will have:

1. legal conditions for e-commerce.

2. the rights and obligations of persons engaged in electronic commerce will be enshrined;

3. rules for making transactions using electronic documents will be determined;

4. recognition of electronic documents as evidence.

The bill, as noted in the Ministry of Economy, will regulate all relationships that arise in e-commerce. According to the bill participants in legal relations in the field of electronic 
commerce are: organizers of auctions, contests and tenders; payment system operators; communication operators (providers); banks; government and non-government organizations; individuals or legal entities.

\section{TURKMENISTAN}

There is a tendency in the development of e-commerce, but no regulations or laws to navigate the relations arising out of these transactions. On May 20, 2020 issues of developing the regulatory framework for e-commerce in the CAREC region were put on the agenda of a video seminar organized jointly with the Asian Development Bank Institute, the Central Asia Institute for Regional Economic Cooperation (CAREC) and the Shanghai National Institute for Accounting. Turkmenistan presented the main directions of state policy in the financial and economic sphere, aimed at improving the national regulatory framework, bringing it in line with international standards, and introducing modern management methods. (1)

Yet, on January 13, 2020 it has been announced that Turkmenistan is preparing a bill on regulation of E-commerce. (2)

\section{TAJIKISTAN}

Due to the limited number of people who have internet access and its high cost, E-commerce in Tajikistan is considered to be in a pre-development state (only $13 \%$ of the whole population to $16 \%$ of the average monthly income of citizens). (3). Furthermore, the blocking and censoring of social media platforms is another stumbling block on the ecommerce progression. There are no regulations or laws to regulate these particular relations as such. There is a little progress in the implementation process of the digital market. In 2018, the taxpayers were granted the right to pay the taxes through the system of electronic payment, but in general it is not deeply integrated among users. (4)

\section{KAZAKHSTAN}

The volume of the e-commerce market in Kazakhstan increased by 1.8 times and exceeded 700 billion tenge in 2019. Importantly, the domestic market is developing more dynamically: the total number of purchases on Kazakhstani online stores amounted to 422 billion tenge in juxtaposition to international Internet sites with 280 billion tenge. In 2019 , the number of active buyers increased by $72 \%$ and amounted to 3.2 million people. Furthermore, more than 2 thousand online stores operate in Kazakhstan yet, only 579 online stores are registered to receive tax benefits in the form of exemption from income tax. During the government meeting chaired by Prime Minister Askar Mamin, Minister of Trade and Integration Bakhyt Sultanov noted that the legal side of this unbalanced growth should be considered and acted accordingly, without over tightening those regulations.

In 2019, the volume of non-cash payments increased 2.3 times which is about 14.4 trillion tenge. The growth is moved by development of the infrastructure of POSterminals, entering Apple Pay and Samsung Pay into the Kazakhstani markets, the stimulation of customers by banks through bonuses and cashbacks, as well as the active use of non-cash payments on all types of public transport. Moreover, 36.8 thousand new jobs were created in the field of e-commerce. (5) Despite this rapid growth Kazakhstan does not rush to enact a separate piece of legislation on e-commerce or digitalization of trade. Nevertheless, the recent bill “Дорожная карта" for 2019-2025 aims to

1. increase to promote the domestic companies in the international platforms in order to raise the level of export; 
2. encourage the international platforms in Kazakhstan. In 2018, the Ministry of Trade and Integration of the Republic of Kazakhstan signed a Memorandum with the international company "Wildberries" on the implementation of the investment project Its main goal is to create and develop infrastructure that will increase the export of Kazakhstani goods through this platform.

3. measures to develop the infrastructure of the e-commerce market ecosystem.

4. full digitalization of the network of agro-logistics and wholesale distribution centers is planned. So, on their basis, electronic trading platforms for farmers and wholesale buyers will be created. The information system will allow tracking goods flows and ensure balanced interregional flows

5. measures aimed at supporting the creation of Kazakhstani digital trading platforms. There are about 13 developing Kazakhstani trading floors in the market. Marketplaces such as Kaspi.kz, flip.kz., chocofamily, mechta.kz and others which have about 20 categories of goods and services.

6. increase the awareness of the population of the digital market and boost their active participation in electronic commerce.

7. To provide proper consumer protection and customer support services regulation in the digital market. (6)

\section{UZBEKISTAN}

Although e-commerce is not one the leading sphere in trade (only 1\%) it has prognosed to raise up to $30 \%$ by 2030 and up to $50 \%$ by 2040 . The main legislation to regulate this issue is code in Constitution called 'Law of the R.Uz on E-Commerce, 29.04.2004 N 613-II' (Amendments in new edition 22.05.2015 N 3PY-385)'. Nonetheless, there is a list of legislation starting from 2004:

1. Regulation of Oliy Majlis of the Republic of Uzbekistan, dated April 29, $2004 \mathrm{~N}$ 614-ii 'About Putting into Action the Law of the Republic of Uzbekistan "About Electronic Commerce"

2. Resolution of the President of the Republic of Uzbekistan, dated November 21, 2006 N PP-513 'On Measures to Improve the Efficiency of Organizing Operational-Search Measures on Telecommunication Networks of the Republic of Uzbekistan'

3. Regulations on the Procedure for Organizing the Use of Technical Means of the System of Operational-Search Measures on Telecommunication Networks of the Republic of Uzbekistan (Appendix to the Decree of the President of the Republic of Uzbekistan dated November 21, 2006 N PP-513)

4. Resolution of the Cabinet of Ministers of the Republic of Uzbekistan dated January 30, 2007 N 21 "On Measures for the Development of Electronic Commerce"

5. Resolution of the Cabinet of Ministers of the Republic of Uzbekistan of 12.06.2007 N 120 "On Measures to Further Improve the Payment Process in the Implementation of Electronic Commerce"

6. Law of the Republic of Uzbekistan dated April 29, 2004 N 613-II "On Electronic Commerce" (New Edition, Approved by the Law of the Republic of Uzbekistan dated May 22, $2015 \mathrm{~N}$ ZRU-385). The aim of the legislation is to regulate the relations in the field of E-commerce

a. Defines what is e-commerce

b. Who are the subjects of e-commerce relation

c. Legal status of e-commerce participants 
d. What Information required from legal or natural person engaged in electronic commerce

e. Information about intermediary service providers

f. Terms of contract in e-commerce

g. Forming of a contract in e-commerce

h. Invitation to make offers in e-commerce

i. Requirements for an offer in e-commerce

j. Use of electronic documents as evidence of a transaction

k. Dispute Resolution

l. Responsibility for breaches (7)

7. Resolution of the Cabinet of Ministers of the Republic of Uzbekistan dated 08.09.2015 N 259 "On Measures to Implement the Law of the Republic of Uzbekistan dated May 22, 2015 N ZRU-385" On Amendments and Additions to the Law of the Republic of Uzbekistan "On Electronic Commerce"

8. Resolution of the Cabinet of Ministers of the Republic of Uzbekistan dated 04.12.2015 N 353 "On Approval of the Concept for the Development of Electronic Commerce in the Republic of Uzbekistan for the period 2016-2018"

9. The Concept of Development of E-Commerce in the Republic of Uzbekistan for the period 2016-2018 (Appendix N 1 to the Resolution of the Cabinet of Ministers of the Republic of Uzbekistan dated 04.12.2015 N 353)

10. Rules for the Implementation of Electronic Commerce (Appendix $\mathrm{N} 1$ to the Resolution of the Cabinet of Ministers of the Republic of Uzbekistan dated 02.06.2016 N 185)

11. Resolution of the Cabinet of Ministers of the Republic of Uzbekistan dated 02.06.2016 N 185 "On Measures to Further Improve the Procedure for Carrying out Transactions in E-Commerce"

12. Regulations on the Procedure for Using Electronic Digital Signatures when Concluding Contracts and Storing Electronic Documents and Information Contained in Electronic Messages Used in Electronic Commerce (Appendix N 2 to the Resolution of the Cabinet of Ministers of the Republic of Uzbekistan dated 02.06.2016 N 185)

13. Resolution of the Cabinet of Ministers of the Republic of Uzbekistan dated 02.08.2016 N 249 "On Approval of the Regulation on the Procedure for Organizing the Activities of Information Intermediaries - Organizers of Electronic Affairs, Auctions and Competitions"

14. Regulation on the Procedure for Organizing the Activities of Information Intermediaries - Organizers of electronic Affairs, Auctions and Competitions (Appendix to the Resolution of the Cabinet of Ministers of the Republic of Uzbekistan dated 02.08.2016 N 249)

15. Resolution of the President of the Republic of Uzbekistan dated May 14, 2018 N PP-3724 "On measures to accelerate the development of electronic commerce"

16. Resolution of the President of the Republic of Uzbekistan dated November 21, 2018 N PP-4022 "On Measures to further Modernize the Digital Infrastructure in order to Develop the Digital Economy"

17. Decree of the President of the Republic of Uzbekistan of 13.12.2018 N UP-5598 "On additional measures to introduce the digital economy, electronic government, as well as information systems in public administration of the Republic of Uzbekistan". (8)

The latest amendment offered by Decree of the President of the Republic of Uzbekistan further promotes: 
- foreign companies with the right to register their subsidiaries in Uzbekistan and enabling them to engage in entrepreneurial (economic) activity without any obstacles

- establish the same legal protections no matter it is a state or private property

- ensure and enforce the property rights.

- implementation of civil legislation in virtual space (i.e Internet),

- the "equalization" of electronic transactions with a written form contract

- regulation of the sale of goods by using electronic communication means

- a comprehensive framework for the circulation of cryptocurrency.

- Uzbek authorities will introduce new types of contracts within the yet to come civil code: travel services, distribution agreements, agency services, escrow agreement.

Moreover, the State Tax Committee submitted a draft resolution for the Cabinet of Ministers observation "On measures to further improve the system of online cash registers and virtual cash registers in the field of trade and services", amending the resolution "On measures to ensure the use of online cash registers and the virtual cash register system" from January 1, 2021, to switch to the use of virtual cash registers. If entrepreneurs switch to using virtual cash registers, subject to registration with the state tax service before January 1, 2021, they are entitled to reduce the amount of accrued and payable income tax or value added tax or a fixed amount of income tax by the amount of expenses related with the introduction of virtual cash registers, but no more than 10 BRVs.

\section{CONCLUSION}

For many countries in Central Asia, developing e-commerce is a long and complicated process given the multi-dimensional challenges discussed above. There is probably no one-size-fits-all solution to all countries until a Central Asia centric approach is adopted. (9) However, one common underlying principle is that any measure aiming to improve e-commerce requires holistic approach and concerted efforts by stakeholders and major players. Besides law developers, consumers must be ethical and responsible to strengthen the virtuous cycle of e-commerce development, in which businesses can win consumer trust, while trade associations and government agencies find it easy to create institution-based trust.

\section{REFERENCES:}

1. CASIAN.INFO. 2021. The Ministry of Finance and Economy of Turkmenistan hosted a webinar on the regulatory framework for e-commerce in the CAREC region. Accessed at https://casian.info/tm/economy/predstaviteli-turkmenistana-prinyaliuchastie-v-obsuzhdenii-normativno-pravovoy-bazy-elektronnoy-kommercii-v-regionecares-24422.html

2. Trend News Agency (2020), E-commerce rules are being prepared in Turkmenistan, Accessex at https://www.trend.az/business/it/3176353.html.

3. Sputnik Tajikistan. 2021. Expert: the lack of Internet hinders the development of the economy of Tajikistan Accessed at https://tj.sputniknews.ru/20170615/dokladvsemirny-bank-internet-ekonomika-tadzhikistan-1022583951.html.

4. Central Asia Analytical Network. 2021. Digital Central Asia: Part Four: E-Commerce (Figures) - Central Asia Analytical Network. Accessed at https://caanetwork.org/archives/13349. 
5. Primeminister.kz. 2021. In 2019, the volume of purchases in Kazakhstani online stores amounted to 422 billion tenge. Accessed at https://primeminister.kz/ru/news/v-2019-goduobem-pokupok-v-kazahstanskih-internet-magazinah-sostavil-422-mlrd-tenge.

6. Zakon.kz. 2021. E-commerce: how the rules for Kazakhstani online stores and online services are changing. Accessed at https://www.zakon.kz/5007258-e-commercekak-menyayutsya-pravila-dlya.html.

7. Law of the Republic of Uzbekistan on Amendments and Addition to the Law of the republic of Uzbekistan "On Electronic Commerce", Accessed at https://www.lex.uz/acts/ 2650295.

8. Nrm.uz. 2021. Legislation of the Republic of Uzbekistan / General issues of economic and entrepreneurial activity /Electronic commerce Accessed at https://nrm.uz/products?folder=438900_elektronnaya_kommerciya\&products=1_zako nodatelstvo_ruz.

9. Ammar Younas (2020), Sustaining Innovative Economy in Fourth Industrial Revolution: A Whitepaper of Uzbek Centered Artificial Intelligence Policy, Available at SSRN 3533410. 